\title{
COMPARATIVE STUDY OF THE EFFECT OF PORTULACA OLERACEA WATER EXTRACT AND CANAGLIFLOZIN (INVOKANA) ON ALLOXAN- INDUCED DIABETES IN ADULT MALE ALBINO RAT
}

By

\author{
Adel Shalaby, Gamal Ahmad Shawer, Hassan Sabry Aly Al-Dawy*, \\ Mohammad Abd El-Hamid Basiuny** and Mohammad Othman Zarad
}

Departments of Medical Physiology, Histology* and Clinical Pathology, ** Al-Azhar Faculty of Medicine

\begin{abstract}
Background: Diabetes mellitus (DM) is the most common endocrine disorder. There is a strong need for new drugs with little adverse effects. Canagliflozin is approved as SGLT2-inhibitor and Portulaca oleracea, herbaceous plant, have a considered efficacy and safety in glycemic control with little side effects.

Objectives: Comparing the effects of Portulaca Oleracea water extract and Canagliflozin (Invokana) on alloxan-induced diabetes in adult male albino rat.

Materials and Methods: Eighty albino rats were randomly categorized into 8 equal groups. Group I (normal control) and group II (diabetic control) were gavaged with normal saline. Three normal groups (groups III, IV, V) and three diabetic groups (groups VI, VII, VIII) were treated with Portulaca Oleracea extract (250 $\mathrm{mg} / \mathrm{kg}$ body weight), Canagliflozin (10 mg/kg body weight) and both Portulaca Oleracea and Canagliflozin in the same doses respectively. Blood and tissue samples were obtained for analysis after 10 weeks of treatment.

Results: More significant reduction occured in serum glucose level by canagliflozin. Elevated liver enzymes, blood urea nitrogen and lipid profile improved more by Portulaca. Portulaca has an antioxidant activity.

Conclusion: Portulaca Oleracea extract is more potent anti-oxidant, tissue protective and regenerative agent for liver and kidney, but weaker hypoglycemic agent than canagliflozin.
\end{abstract}

Key words: Portulaca Oleracea, Canagliflozin, diabetes.

\section{INTRODUCTION}

Diabetes mellitus represents a global health problem because of its possible complications. It is one of the leading causes of death. It is considered the third greatest "killer" after cancer (Ketan and Annapurna, 2014). So, it needs to be treated urgently as hyperglycemia causes multiorgan damage which decreases quality of life (Parveen et al., 2015).

Complementary medicine can offer novel, safe, and cost-effective options for regulating plasma glucose levels and blood lipid profiles (Hadi et al., 2018). One form of these complementary 
medicines is theuse of herbaceous plants such as Portulaca oleracea.

Sodium glucose co-transporter 2 inhibitors represent a new class of oral anti-diabetic agents with a novel mechanism that inhibits glucose reabsorption, allowing glucose to be excreted (Zurek et al., 2017).

The present work was designed to compare the effect of Portulaca Oleracea water extract and Canagliflozin (Invokana) on alloxan-induced diabetes in adult male albino rat.

\section{MATERIALS AND METHODS}

Eighty adult male albino rats of a local strain were chosen as an animal model of this study. Weight of rats ranged between 80-120 g. they were kept in cages $(35 \times 45 \times 35 \mathrm{~cm}$-for every 5 rats). They were kept for 10 days to adapt to normal temperature and normal dark/ light cycle, and feds on rats pellets and green vegetables in addition to water ad lib. They were randomly categorized into 8 equal groups:

1-Nomal control group treated with normal saline received $2 \mathrm{ml}$ normal saline by gavaging daily.

\section{2- Diabetic control group treated with} normal saline received $2 \mathrm{ml}$ normal saline by gavaging daily.

\section{3- Normal control group treated with}

Portulaca only received $250 \mathrm{mg} / \mathrm{kg}$

Portulaca Oleracea extract by gavaging daily (Lee et al., 2012).

4- Normal control group treated with Invokana only received $10 \mathrm{mg} / \mathrm{kg} /$ day Invokana by gavaging daily (Yin et al., 2012).
5- Normal control group treated with Portulaca and Invokana: received 250 $\mathrm{mg} / \mathrm{kg}$ Portulaca Oleracea extract and 10 $\mathrm{mg} / \mathrm{kg}$ Invokana daily .

6- Diabetic group treated with Portulaca only received $250 \mathrm{mg} / \mathrm{kg}$ Portulaca Oleracea extract by gavaging daily.

7- Diabetic group treated with Invokana only received $10 \mathrm{mg} / \mathrm{kg} /$ day Invokana by gavaging daily.

8- Diabetic group treated with Portulaca and Invokana received 250 $\mathrm{mg} / \mathrm{kg}$ Portulaca Oleracea extract and 10 $\mathrm{mg} / \mathrm{kg}$ Invokana daily.

Experimental procedure continued for 10 weeks.

Diabetes mellitus was induced by a single IP injection of alloxan at a dose of $160 \mathrm{mg} / \mathrm{kg}$ (Szkudelski, 2001). This was preceded by single IP injection of nicotinamide at a dose of $110 \mathrm{mg} / \mathrm{kg}$ to alleviate alloxan toxicity (Madkor et al., 2011).

Canagliflozin ( Invokana; 300mg ) was purchased from Janssen Pharmaceutical Industries, USA. Each white tablet contained $118 \mathrm{mg}$ lactose as an inactive ingredient. The tablets were crushed, dissolved in distilled water and given orally in a dose of $10 \mathrm{mg} / \mathrm{kg} /$ day (Yin et al., 2012).

Preparation of Portulaca water extract: After taxonomical identification of the plant, the collected leaves were dried at room temperature for seven days and ground in to a powder. This powder was boiled at $60 \sim 70{ }^{\circ} \mathrm{C}$ in distillated water (at a ratio of $1 \mathrm{~g}$ per $9 \mathrm{ml}$ ) for 30 minutes, and the decoction were filtered through cotton 
wool. The filtrate was concentrated at $65^{\circ} \mathrm{C}$ by a rotavapor before lyophilization, dissolved in distilled water, and was given at daily dose of $250 \mathrm{mg} / \mathrm{kg}$ for 10 weeks (Lee et al., 2012).
Blood samples and tissue sections of liver, kidney and pancreas were obtained for analysis at the end of experiment.

\section{RESULTS}

Invokana reduced serum glucose level significantly more thaPortulaca without increase in fasting serum insulin level in diabetic group (Table 1).

Table (1): Effect of Portulaca Oleracea and Invokana on Fasting Blood Sugar FBS $(\mathrm{mg} / \mathrm{dl})$ and Fasting serum Insulin $(\mathrm{ng} / \mathrm{ml})($ mean \pm SD)

\begin{tabular}{|cl|c|c|}
\hline Groups & FBS(mg/dl) & Insulin (ng/ml) \\
\hline Group 1 & (Normal) & $84.5 \pm 7.96$ & $34.2 \pm 2.25$ \\
\hline Group 2 & (Diabetic) & $284.1 \pm 25.59$ & $5.68 \pm 1.07$ \\
\hline Group 3 & (Portulaca) & $84.65 \pm 2.33$ & $32.28 \pm 1.99$ \\
\hline Group 4 & (Invokana) & $84.3 \pm 4.40$ & $32.02 \pm 1.81^{\mathbf{a}}$ \\
\hline Group 5 & (Portulaca + Invokana) & $84.6 \pm 6.95$ & $32.2 \pm 2.02$ \\
\hline Group 6 & (Diabetic- Portulaca) & $111 \pm 7.64^{\mathbf{b , d}}$ & $6.23 \pm 1.16^{\mathbf{d}}$ \\
\hline Group 7 & (Diabetic- Invokana) & $101.6 \pm 5.6^{\mathbf{b , c}, \mathbf{e}}$ & $5.69 \pm 1.08^{\mathbf{e}}$ \\
\hline
\end{tabular}

(a) Significance versus normal control group

(b) Significance versus diabetic control group

(c) Significance versus group (6)

(e) Significance versus group (4)

(d) Significance versus group (3)

(f) Significance versus group (5)

Table (2): Effect of Portulaca Oleracea and Invokana on liver Functions $($ mean \pm SD)

\begin{tabular}{|c|c|c|c|}
\hline Groups $\quad$ Parameters & $\operatorname{AST}(\mathbf{U} / \mathbf{L})$ & $\operatorname{ALT}(\mathbf{U} / \mathbf{L})$ & $\operatorname{Albumin}(\mathbf{g} / \mathbf{d l})$ \\
\hline Group 1 ( Normal ) & $28.6 \pm 2.01$ & $29.7 \pm 4.45$ & $4.1 \pm 0.25$ \\
\hline Group 2 (Diabetic ) & $72.4 \pm 5.30$ & $55.7 \pm 8.01$ & $3.6 \pm 0.40$ \\
\hline Group 3 (Portulaca) & $27.6 \pm 2.32$ & $28.2 \pm 5.79$ & $4.09 \pm 0.27$ \\
\hline Group 4 (Invokana ) & $40.1 \pm 6.12^{\mathbf{a}, \mathbf{d}}$ & $29.9 \pm 6.03$ & $4.07 \pm 0.26$ \\
\hline Group 5 (Portulaca + Invokana) & $27.5 \pm 2.32$ & $28.1 \pm 4.23$ & $4.08 \pm 0.30$ \\
\hline Group 6 (Diabetic- Portulaca ) & $39.2 \pm 5.67^{\mathbf{b , d}}$ & $29.7 \pm 5.95^{\mathbf{b}}$ & $3.6 \pm 0.32^{d}$ \\
\hline Group 7 (Diabetic- Invokana ) & $45.2 \pm 2.20^{\mathbf{b}, \mathbf{c}, \mathbf{e}}$ & $43.6 \pm 4.43^{\mathbf{b , c , e}}$ & $3.6 \pm 0.40$ \\
\hline Group 8 (Diabetic - P. + Invokana) & $46.1 \pm 0.37^{\mathbf{b , f}}$ & $29.9 \pm 3.56^{\text {b,f }}$ & $3.73 \pm 10.32^{b, f}$ \\
\hline
\end{tabular}
(a) Significance versus normal control group
(c) Significance versus group (6)
(b) Significance versus diabetic control group
(d) Significance versus group (3)
(e) Significance versus group (4)
(f) Significance versus group (5) 

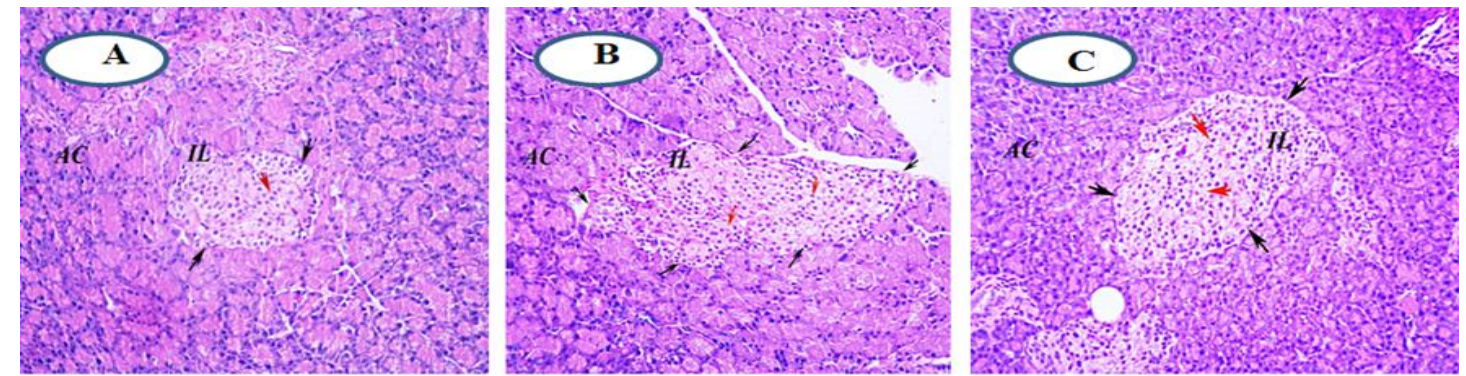

Figure (1): A photomicrograph of a pancreatic tissue (H \& E x400) showing:

pancreatic acini (AC) and an islet of Langerhans (IL) with a clear separation line between them (black arrows). The islet shows some restoration of the cord arrangement of the cells (red arrow).

(A) Diabetic group treated with portulaca

(B) Diabetic group treated with Invokana

(C)Diabetic group treated with Portulaca and Invokana
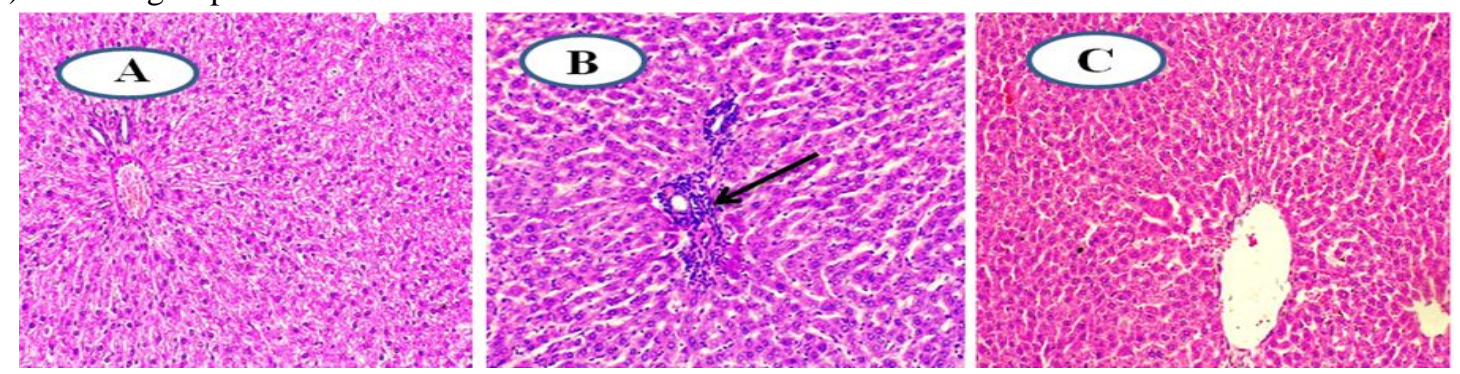

Figure (2): A photomicrograph of a liver tissue of groups 6, 7 and 8 (H \& E x400)

A (Diabetic group treated with portulaca): less similar to control group showed some inflammatory cells and some vacuolated cells

B (Diabetic group treated with Invokana) showed more inflammatory cells (black arrow) and vacuolated cells C (Diabetic group treated with Portulaca and Invokana) more or less similar to control group
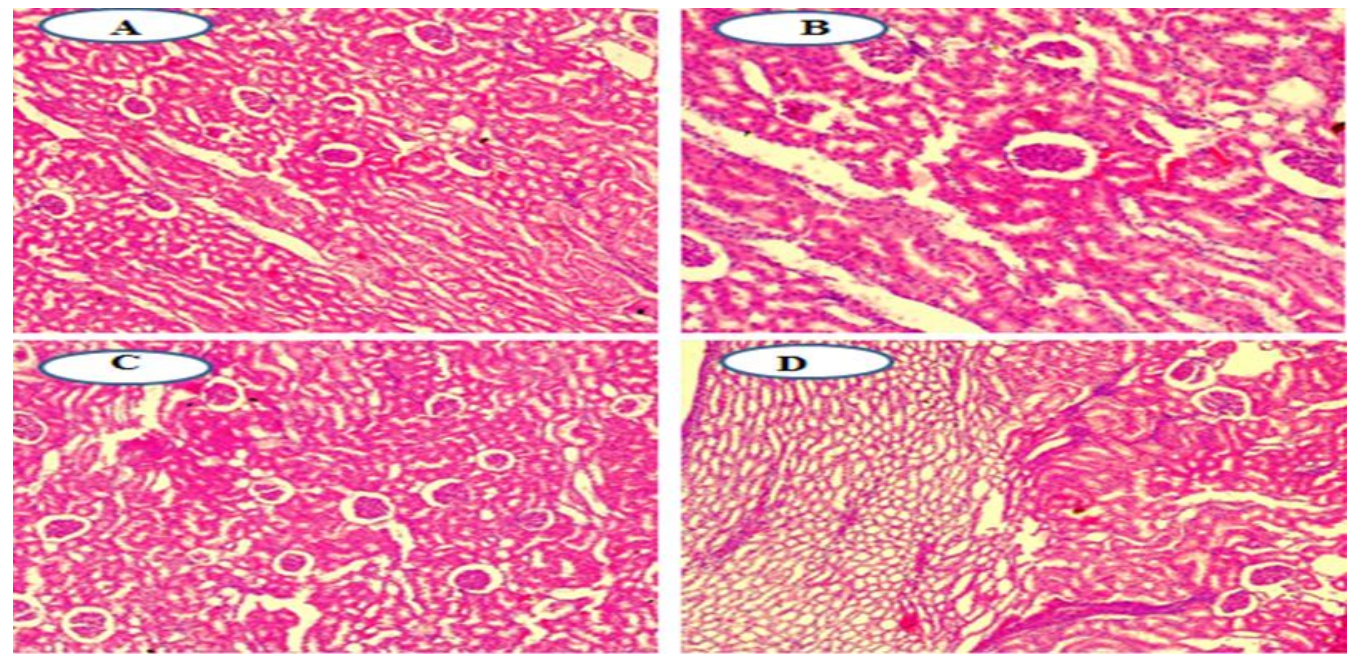

\section{Figure (3): A photomicrograph of a renal tissue ( $\mathrm{H} \& \mathrm{E} \quad \mathrm{x400})$}

A (Normal control group) normal glomerular structure, tubules and collecting ducts

B (Diabetic group treated with no treatment) showing disturbed glomerular basement membrane with chronic inflammatory cell infiltration .

C (Diabetic group treated with portulaca) showing markedly preserved glomerular and tubular structure.

D (Diabetic group treated with Invokana) showing moderately preserved glomerular and tubular structure, but some inflammatory cell infiltration is present. 
Histopatholological sections of pancreatic tissue revealed marked improvement of degeneration and necrosis in diabetic group (Fig. 1).

Portulaca and Invokana reduced elevated liver enzymes in diabetic group, but Portulaca reduced liver enzymes more than Invokana (Table 2).

These results were supported by histopathological examination of liver tissue as sections showed improvement in inflammatory cells and vacuolated cells, and become less similar to control group. The improvement was clear in Portulaca sections more than Invokana (Fig.2).
Serum creatinine showed no changes with Portulaca and Invokana treatments. Invokana caused increase in serum BUN level in normal group. In diabetic group, Portulaca and Invokana decreased serum BUN level but Portulaca was more effective (Table 3) .

Histopathological sections showed that preservation of glomerular and tubular structure was less in diabetic group treated with Invokana, and some inflammatory cell infiltration were present (Fig.3) .

Table (3): Effect of Portulaca and invokana on kidney functions (Mean \pm SD)

\begin{tabular}{|c|c|c|}
\hline $\begin{array}{ll}\text { Groups } & \text { Parameters } \\
\end{array}$ & Creatinine $(\mathrm{mg} / \mathrm{dl})$ & $\mathbf{B U N}(\mathrm{mg} / \mathrm{dl})$ \\
\hline Group 1 ( Normal ) & $0.99 \pm 0.21$ & $16.2 \pm 2.57$ \\
\hline Group 2 (Diabetic ) & $1.15 \pm 0.16$ & $30 \pm 3.74$ \\
\hline Group 3 (Portulaca) & $0.98 \pm 0.15$ & $14.3 \pm 2.36$ \\
\hline Group 4 (Invokana ) & $1.09 \pm 0.18$ & $28.4 \pm 4.53^{\mathrm{a,d}}$ \\
\hline Group 5 (Portulaca +Invokana ) & $1.03 \pm 0.19$ & $21.4 \pm 4.74^{\mathrm{a}}$ \\
\hline Group 6 (Diabetic:Portulaca ) & $0.98 \pm 0.15$ & $14.3 \pm 2.36^{\mathbf{b}}$ \\
\hline Group 7 (Diabetic:Invokana ) & $1.14 \pm 0.15$ & $21.8 \pm 5.05^{\mathbf{b , c , e}}$ \\
\hline Group8 (Diabeti:Portulaca+invokana) & $1.02 \pm 12.05$ & $19 \pm 0.68^{\mathbf{b , f}}$ \\
\hline
\end{tabular}

(a) Significance versus normal control group

(b) Significance versus diabetic control group

(c) Significance versus group (6)

(e) Significance versus group (4)

(d) Significance versus group (3)

(f) Significance versus group (5)

Portulaca improved lipid profile in diabetic rats as it decreased serum triglycerides, LDL, total cholesterol and increased serum HDL, while Invokana increasd serum LDL and caused similar effects of Portulaca on other lipid profile markers (Table 4). 


\section{ADEL SHALABY et al.}

Table (4): Effect of Portulaca Oleracea and Invokana on lipid profile (mean \pm SD)

\begin{tabular}{|l|r|r|r|r|}
\hline \multicolumn{1}{|c|}{ Parameters } & \multicolumn{1}{|c|}{$\begin{array}{c}\text { Cholesterol } \\
(\mathrm{mg} / \mathrm{dl})\end{array}$} & $\begin{array}{c}\text { Triglycerides } \\
(\mathrm{mg} / \mathrm{dl})\end{array}$ & \multicolumn{1}{c|}{$\begin{array}{c}\text { HDL } \\
(\mathrm{mg} / \mathrm{dl})\end{array}$} & \multicolumn{1}{c|}{$\begin{array}{c}\text { LDL } \\
(\mathrm{mg} / \mathrm{dl})\end{array}$} \\
\hline Group 1 (Normal) & $139.9 \pm 4.58$ & $99.2 \pm 10.35$ & $40.2 \pm 4.83$ & $79.86 \pm 7.16$ \\
\hline Group 2 (Diabetic) & $208.6 \pm 43.48$ & $181.2 \pm 9.26$ & $34.6 \pm 4.48$ & $137.76 \pm 44.24$ \\
\hline Group 3 (Portulaca) & $131.3 \pm 11.06$ & $92.8 \pm 11.96$ & $41.4 \pm 2.01$ & $71.34 \pm 10.37$ \\
\hline Group 4 (Invokana) & $130.6 \pm 10.29$ & $89.3 \pm 9.45^{\mathbf{a}}$ & $41.5 \pm 1.27$ & $86.84 \pm 3.52$ \\
\hline $\begin{array}{l}\text { Group 5 (Portulaca }+ \\
\text { Invokana) }\end{array}$ & $130.1 \pm 10.32$ & $89.2 \pm 6.03^{\mathbf{a}}$ & $41.5 \pm 2.01$ & $70.76 \pm 9.55$ \\
\hline $\begin{array}{l}\text { Group 6 (Diabetic- } \\
\text { Portulaca) }\end{array}$ & $134.7 \pm 6.72^{\mathbf{b}}$ & $101.3 \pm 13.12^{\mathbf{b}}$ & $34.6 \pm 4.48^{\mathbf{d}}$ & $79.84 \pm 9.75$ \\
\hline $\begin{array}{l}\text { Group 7 (Diabetic- } \\
\text { Invokana) }\end{array}$ & $131.3 \pm 11.06^{\mathbf{b}}$ & $92.8 \pm 11.96^{\mathbf{b}}$ & $41.4 \pm 2.01^{\mathbf{b , c}}$ & $143.9 \pm 7.55^{\mathbf{c}, \mathbf{e}}$ \\
\hline $\begin{array}{l}\text { Group 8 (Diabetic - P. }+ \\
\text { inv.) }\end{array}$ & $133.3 \pm 4.60^{\mathbf{b , f}}$ & $106.5 \pm 8^{\mathbf{b}, \mathbf{f}}$ & $34 \pm 0.83^{\mathbf{b , f}}$ & $144.8 \pm 7.35^{\mathbf{b , f}}$ \\
\hline
\end{tabular}

(a) Significance versus normal control group

(b) Significance versus diabetic control group

(e) Significance versus group (4) (c) Significance versus group (6)

(d) Significance versus group (3)

(f) Significance versus group (5)

Portulaca oleracea has a potent antioxidant activity. It caused a significant decrease in serum MDA level, and

increase in serum SOD, catalase and GSH in diabetic group (Table 5).

Table (5): Effect of Portulaca Oleracea and Invokana on antioxidants profile $($ Mean \pm SD)

\begin{tabular}{|c|c|c|c|c|}
\hline$\overbrace{\text { Groups }}$ Parameters & $\begin{array}{c}\text { MDA } \\
(\text { nmol/ml })\end{array}$ & SOD(nmol/ml) & $\begin{array}{l}\text { Catalase } \\
(\mathrm{pg} / \mathrm{ml})\end{array}$ & GSH (mg/dl) \\
\hline Group 2 (Diabetic) & $5.66 \pm 0.87$ & $96.1 \pm 7.16$ & $25.5 \pm 3.60$ & $8.58 \pm 1.15$ \\
\hline Group 3 (Portulaca) & $1.11 \pm 0.45$ & $146.8 \pm 7.54$ & $43.1 \pm 2.92$ & $13.19 \pm 1.95$ \\
\hline Group 4 (Invokana ) & $5.78 \pm 0.75^{\text {a,d }}$ & $102.6 \pm 10.32^{\text {a,d }}$ & $33.1 \pm 3.93^{\mathbf{a , d}}$ & $10.58 \pm 1.01^{\mathrm{a}, \mathrm{d}}$ \\
\hline Group 5 (Portulaca + Inv. & $1.11 \pm 0.37$ & $146.8 \pm 7.51$ & $40.2 \pm 3.49$ & $13.19 \pm 1.95$ \\
\hline Group 6 (Diabetic+ Port.) & $2.06 \pm 0.27^{\mathbf{b}}$ & $122.4 \pm 6.24^{\mathbf{b , d}}$ & $31.1 \pm 2.27^{\mathbf{b , d}}$ & $11.01 \pm 0.81^{\mathbf{b , d}}$ \\
\hline Group 7 (Diabetic- Inv.) & $5.56 \pm 0.89^{\mathrm{c}}$ & $96.7 \pm 7.17^{c}$ & $26.3 \pm 3.68^{\mathbf{c}, \mathbf{e}}$ & $9.1 \pm 1.11^{\mathrm{c}, \mathrm{e}}$ \\
\hline $\begin{array}{l}\text { Group } 8 \text { (Diabetic - P. + } \\
\text { inv.) }\end{array}$ & $2.28 \pm 3.51^{\mathbf{b}, \mathbf{f}}$ & $118.4 \pm 0.79^{\mathbf{b , f} f}$ & $33.05 \pm 3.51^{\mathbf{b , f}}$ & $11.37 \pm 0.79^{\mathbf{b , f}}$ \\
\hline
\end{tabular}
(a) Significance versus normal control group
(c) Significance versus group (6)
(b) Significance versus diabetic control group
(d) Significance versus group (3)
(e) Significance versus group (4)
(f) Significance versus group (5) 


\section{DISCUSSION}

Although there are available effective and well-tolerated treatments of diabetes, still many patients could not attain recommended glycemic level (Chaudhury et al., 2017). Complementary medicine can offer novel, safe, and cost-effective options for regulating plasma glucose levels and blood lipid profiles (Hadi et al., 2018). One form of these complementary medicines is the use of herbaceous plants such as Portulaca oleracea.

Sodium-glucose co-transporter 2 (SGLT2) inhibitors are a new category of diabetic medications indicated just for the treatment of type 2 diabetes. Along with exercise and a healthy diet, they can improve glycemic control (Zurek et al., 2017).

The current study showed significant increase in blood glucose levels after alloxan injection of the rats. (Etuk \& Muhammed, 2010) and (Adeyi et al., 2012) attributed this increase in glucose levels to the reactive oxygen species induced by alloxan. This, in conjunction with a simultaneous massive increase in cytosolic calcium concentrations led to rapid destruction of pancreatic islet cells and a concomitant reduction in synthesis/release of insulin. This was confirmed here by histopathological results in alloxan-treated rats, as there were marked reduction in the size of cellular components of the islet cells along with variable levels of degeneration and the appearance of apoptotic cells. Such outcomes were in line with those of (Adeyemi et al., 2015) who noted a significant reduction in the numerical density of islet cells (number/pancreas), islet cell area and diameter and $\beta$-cell density in diabetic rats.

Blood glucose level revealed that Portulaca reduced serum glucose level significantly compared to diabetic group. This result was in agreement with the findings of (Gu et al., 2015), (Bai et al., 2016), (Ramadan et al., 2017), (Park et al., 2018). This may be due to the potentiation of insulin secretion from $\beta$ islet cells (Ramadan et al., 2017), enhancement of the translocation of GLUT4 to the plasma membrane, enhancement of glucose uptake through the PI3K/Akt pathway (Park et al., 2018), or increase in the amount of GLP1 (Heidarzadeh et al., 2013).

In the present study, Invokana reduced serum glucose level significantly more than portulaca. This could be attributed to its beta cell-independent mechanism (Zurek et al., 2017).

This study showed non-significant decrease in diabetic group treated with Invokana when compared to diabetic Portulaca group. This may be in connection with increasing insulin secretion by Portulaca through closing of the channel gate ATP-K+, membrane depolarization and $\mathrm{Ca} 2+$ entry stimulation as the first key step in insulin secretion (Gong and Li, 2009). Also, increase the amount of GLP-1 as an affecting marker on pancreatic beta cells and insulin may be a contributing factor (Heidarzadeh et al., 2013).

Reduction of elevated liver enzymes in diabetic group results were constant with that obtained in a study performed by (Leiter et al., 2016), (Gautam et al., 2018) and (Li et al., 2018). This may due to hypoglycemic, anti-inflammatory and 


\section{ADEL SHALABY et al.}

immunomodulatory effects of Portulaca (Kaveh et al., 2017), and antioxidant enzymes activities of Portulaca (Chen et al., 2016). Canagliflozin besides controlling the blood sugar level also reduced the weight of patients of type 2 diabetes which improves liver enzymes (Gautam et al., 2018).

Improvement of lipid profile with Portulaca was in agreement with (ElNewary, 2016), (Iranshahy et al., 2017), (Hadi et al., 2018) and (Nazeam et al., 2018). This improvement may be due to control of diabetes and active ingredient of Portulaca as omega-3 fatty acids content (Hadi et al., 2018).

Canagliflozin was associated with increase in plasma levels of low-density lipoprotein potentially resulting from metabolic changes such as increased lipoprotein lipase activity, but the exact mechanism is unknown (Zurek et al., 2017).

Increase of serum BUN in Invokana in normal group may due to dehydration due to osmotic diuresis as increased serum urea is seen associated with such conditions (Gowda et al., 2010).

Portulaca possesses marked nephroprotective activity, and have a promising role in the treatment of acute renal injury induced by nephrotoxins (Ghara and Ghadi, 2018).

Improvement of antioxidant profile with Portulaca was in agreement with (Ghorbani et al., 2013) and (Sadeghi et al., 2016). The alkaloids including oleracein A, oleracein B and oleracein $\mathrm{E}$ found in purslane have shown antioxidant activity based on scavenging activity against 1,1-diphenyl- 2-picryl-hydrazyl
(DPPH) radical, and inhibitory impact on hydrogen peroxide-induced lipid peroxidation in rat brain homogenates (Sadeghi et al., 2016).

\section{CONCLUSION}

Both Portulaca oleracea and Canagliflozin have values in diabetic management, but Canagliflozin was more potent. Also, both agents showed hepatic protective effects against diabetic induced hepatic injury with the upper hand for portulaca. Portulaca can prevent pathogenesis of diabetic complications namely hyperlipedemia, oxidative stress, renal impairement and stimulating inflammatory processes more than canagliflozin.

\section{REFERENCES}

1. Adeyemi DO, Komolafa OA, Adewole OS, Obuotor EM, Abiodun AA and Adenowo TK (2010): Histomorphological and morphometric studies of the pancreatic islet cells of diabetic rats treated with extract of Annonamuricata. Folia Morphol., 69(2):92100 .

2. Adeyi A, Idowu B, Mafiana C, Oluwalana S, Ajayi $O$ and Akinloye $O$ (2012): Rat model of food-induced non-obese-type 2 diabetes mellitus: comparative pathophysiology and histopathol-ogy. Intl J Physiol Pathophysiol Pharmacol., 1:51-8.

3. Bai Y, Zang X, Ma J and Xu G (2016): AntiDiabetic Effect of Portulaca oleracea L. Polysaccharideandits Mechanism in Diabetic Rats. Int. J. Mol. Sci., 17(8): 1201-14.

4. Chaudhury A, Duvoor C, Dendi VS, Kraleti S, Chada A, Ravilla R, Marco A, Shekhawat NS, Montales MT, Kuriakose K, Sasapu A, Beebe A, Patil N, Musham CK, Lohani GP and Mirza W (2017): Clinical Review of Antidiabetic Drugs: Implications for Type 2 Diabetes Mellitus Forst Management., Front Endocrinol (Lausanne), 17(8):1-6. 
5. Chen L, Liu Y, Jia D, Yang J, Zhao J, Chen $C$, Liu $H$ and Liang $X$ (2016): Pharmacokinetics and biodistribution of aurantiamide and aurantiamide acetate in rats after oral administration of Portulaca oleracea L. extracts. J. Agric. Food Chem., 64: 34453455 .

6. El-Newary SA (2016): The hypolipidemic effect of Portulaca oleracea L. stem on hyperlipidemic Wister Albino rats. Annals of Agricultural Science, 61(1): 111-124.

7. Etuk E and Muhammed B (2010): Evidencebased analysis of chemical method of induction of diabetes mellitus in experimental animals. Asian J Exp Biol., 1:331-6.

8. Gautam A, Agrawal PK, Doneria $J$ and Nigam A (2018): Effects of Canagliflozin on Abnormal Liver Function Tests in Patients of Type 2 Diabetes with Non-Alcoholic Fatty Liver Disease. Journal of The Association of Physicians of India, 66(1): 62-65.

9. Ghara AR and Ghadi FE (2018): Effect of purslane on kidney failure following copper toxicity in a rat model. Iranian Journal of Health Sciences, 6(1): 25-32.

10. Ghorbani MR, Bojarpur M, Mayahi M, Fayazi J, Fatemitabatabaei $\mathbf{R}$ and Tabatabaei S (2013): Effect of purslane (Portulaca oleracea L.) on blood lipid concentration and antioxidant status of broiler chickens. Online J. Vet. Res., 17, 54-63.

11. Gong F and Li F (2009): Hypoglycemic Effects of Crude Polysaccharide from Purslane. Int. J. Mol. Sci., 10:880-8.

12. Gowda S, Desai PB, Kulkarni SS, Hull VV, Math AA and Vernekar SN (2010): Markers of renal function tests. N Am J Med Sci., 2(4): $170-173$.

13. Gu JF, Zheng ZY, Yuan JR, Zhao BJ, Wang CF, Zhang L, Xu QY, Yin GW, Feng $L$ and Jia XB (2015): Comparison on hypoglycemic and antioxidant activities of the fresh and dried Portulaca oleracea L. in insulin-resistant HepG2 cells and streptozotocin-induced $\mathrm{C} 57 \mathrm{BL} / 6 \mathrm{~J}$ diabetic mice. J Ethnopharmacol., 161:214-23.

14. Hadi A, Pourmasoumi M, Najafgholizadeh A, Kafeshani M and Sahebkar A (2018):
Effect of purslane on blood lipids and glucose: A systematic review and meta-analysis of randomized controlled trials. Phytotherapy Research, 18:1-10.

15. Heidarzadeh S, Farzanegi P, Azarbayjani MA and Daliri R (2013): Purslane Effect on GLP-1 and GLP-1 receptor in type 2 diabetes. Electronic Physician, 5(1): 582-87.

16. Iranshahy M, Javadi B, Iranshahi $M$, Jahanbakhsh SP, Mahyari S, Hassani FV and Karimi G (2017): A review of traditional uses, phytochemistry and pharmacology of Portulaca oleracea L. J Ethnopharmacol., 9(205):158-172.

17. Kaveh M, Eidi A, Nemati A and Boskabady MH (2017): Modulation of lung inflammation and immune markers in asthmatic rats treated by Portulaca Oleracea. AJP, 7(5): 409-16.

18. Ketan H and Annapurna A (2014): The effect of quercetin on blood glucose levels of normal and streptozotocin induced diabetic (type i \& type ii) rats. IJPCBS, 4(3):613-9.

19. Lee AS, Lee YJ, Lee SM, Yoon JJ, Kim JS, Kang DG and Lee HS (2012): An Aqueous Extract of Portulaca Oleracea Ameliorates Diabetic Nephropathy Through Suppression of Renal Fibrosis and Inflammation in Diabetic $\mathrm{db} / \mathrm{db}$. MiceThe American Journal of Chinese Medicine, 40 (3): 495-510.

20. Leiter LA, Forst T, Polidori D, Balis DA, Xie $J$ and Sha $S$ (2016): Effect of Canagliflozin on liver function tests in patients with type 2 diabetes. Diabetes Metab., 42 (1): 25-32.

21. Li B, Wang Y, Ye Z, Yang H, Cui X, Wang $Z$ and Liu L (2018): Effects of Canagliflozin on Fatty Liver Indexes in Patients with Type 2 Diabetes: A Meta-analysis of Randomized Controlled Trials, J Pharm Pharm Sci., 21(1):222-235.

22. Madkor HR, Mansour SW and Ramadan G (2011): Modulatory effects of garlic, ginger, turmeric and their mixture on hyperglycaemia, dyslipidaemia and oxidative stress in streptozotocin - nicotinamide diabetic rats. British Journal of Nutrition, 105: 1210-1217.

23. Nazeam JA, El-Hefnawy HM, Omran G and Singab A (2018): Chemical profile and 


\section{ADEL SHALABY et al.}

antihyperlipidemic effect of Portulaca oleracea L. seeds in streptozotocininduced diabetic rats. Natural Product Research, 32(12): 1484-1488.

24. Park JE, Lee JS, Lee HA, and Han JS (2018): Portulaca oleracea L. Extract Enhances Glucose Uptake by Stimulating GLUT4 Translocation to the Plasma Membrane in 3T3L1 Adipocytes. J Med Food, 2018: 1-7.

25. Parveen R, Agarwal NB, Kaushal N, Mali G and Raisuddin S (2015): Efficacy and safety of Canagliflozin in type 2 diabetes mellitus: systematic review of randomized controlled trials. Expert Opin Pharmacother., 9:1-11.

26. Ramadan BK, Schaalan MF and Tolba AM (2017): Hypoglycemic and pancreatic protective effects of Portulaca oleracea extract in alloxan-induced diabetic rats. BMC Complementary and Alternative Medicine, 17:37-38.

27. Sadeghi G, Karimi A, Shafeie F, Vaziry A and Farhadi D (2016): The Effects of purslane (Portulaca oleracea L.) powder on growth performance, carcass characteristics, antioxidant status, and blood metabolites in broiler chickens. Livestock Science, 184 (16): $35-40$.

28. Szkudelski T (2001): The mechanism of alloxan and streptozotocin action in $\beta$ cells of rat pancreas. Physiology Research Journal, 50: 536-546.

29. Yin L, Kenji A, Kiichiro U, Matsushita $Y$, Kuriyama C, Martin T, Du F, Liu Y, Xu J, Conway B, Conway J, Polidori D, Ways $\mathrm{K}$ and Demarest $K$ (2012): Effect of Canagliflozin on Renal Threshold for Glucose, Glycemia, and Body Weight in Normal and Diabetic Animal Models. Plos One, 7 (2): 1-7.

30. Zurek AM, Yendapally $R$ and Urteaga EM (2017): A Review of the Efficacy and Safety of Sodium-Glucose Cotransporter 2 Inhibitors: A Focus on Diabetic Ketoacidosis. Diabetes Spectr., 30(2): 137-142. 


\section{در اسة مقارنة لتأثير الخلاصة المائية لنبات البقلة (الرجلة)

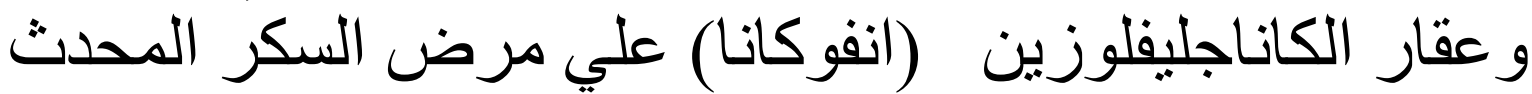 بالألوكسان في ذكور الجرذان البيضوناء البانية}

عادل شلبي - جمال أحمد شـاور- حسن صبري علي الضسوي * ـ محمد عبد الحميد بسيوني **-ـ محمد عثمان زَرَد

أقسام الفسيولوجيا الطبية و الهستولوجيا * و الباثولوجيا الإكلينيكية ** ، كلية طب الأزهر

خلفية البحث : مرض البول السكري هو الاضطر اب الأكثر شيو عا للغدد الصماء، ورغم توفر العديد

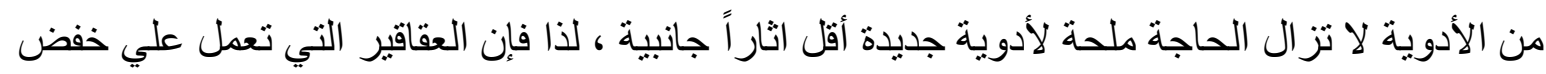

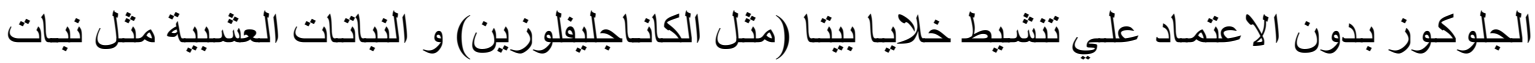
البقلة ( الرجلة ) لها فعالية عالية في التحكم في نسبة السكر في الدم مع آثار جانبية ضئيلة.

الهـدف مـن البحـث: مقارنــة تـأثير العـلاج بالخلاصــة المائيسة لنبـات الرجلـة وعقار الكانـاجليفلوزين

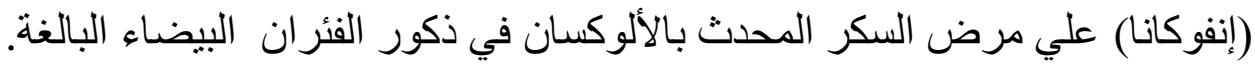

مواد والأسـاليب: استخدم في هذا البحث ثمـانون فأرا ذكرا أبيضـا من السـلالات المحلية كنموذج لللار اسة وقد قسمت الفئران إلي ثمان مجمو عات متساوية:

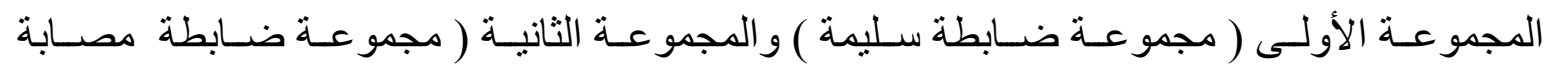
بالسكري) تم إعطاؤ هما محلول ملحي بالفم.

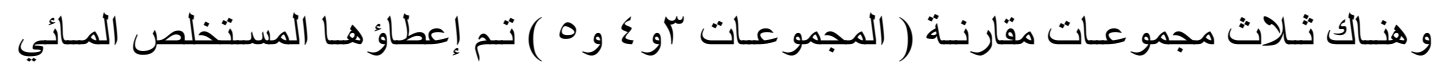

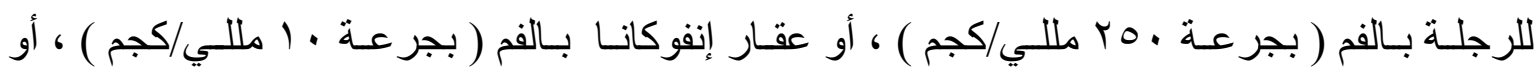

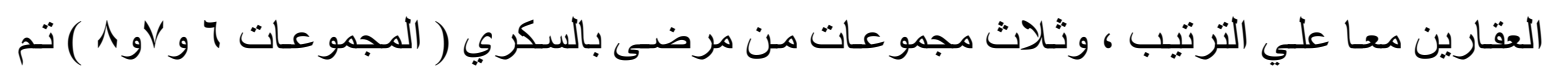
إعطاؤها نفس جر عات مجمو عات المقارنة.

و بعد · ا أسـاييع من العلاج تم سحب عينات من الدم كما تم أخذ عينـات من الكبد و الكلي و البنكرياس للار اسة النسيجية. 


\section{ADEL SHALABY et al.}

النتائج: تسبب حقن الألوكسان في ارتفاع نسبة السكر و إنزيمات الكبد و الدهون) عدا البروتين الدهني

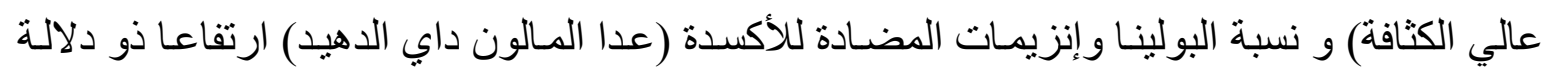
إحصائية عند مقارنتها بالمجمو عة الضابطة الأولي.

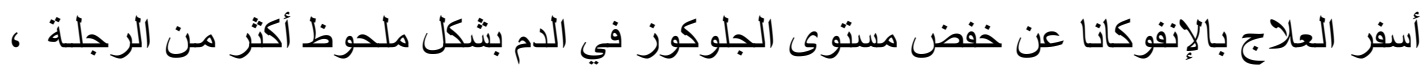

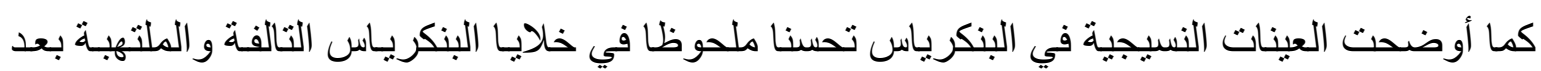
العلاج بالإنفوكانا أو الرجلة أو كليهما.

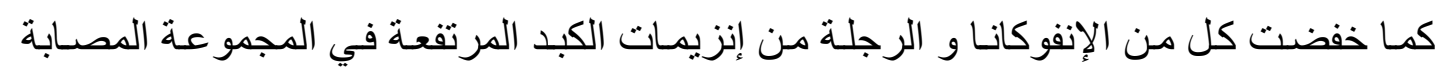

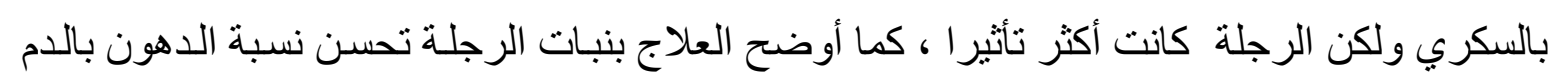

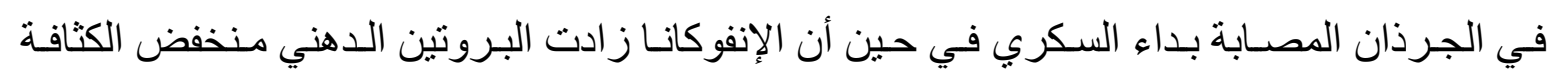

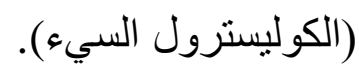

وقد أوضحت الدراسة أن نبات الرجلة له نثاط قوي مضاد للأكسدة ، بينما الإنفو كانا لم يثبت له تأثير مضاد للأكسدة.

الاستنتاج: الكاناجليفلوزين أكثر فاعلية في خفض نسبة السكر من نبات الرجلة ، كما أن كلا من نبات

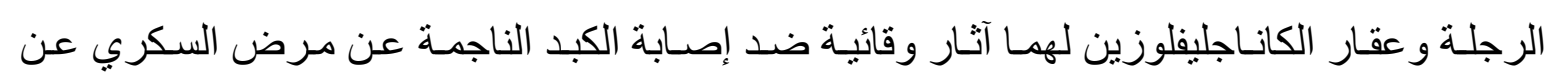

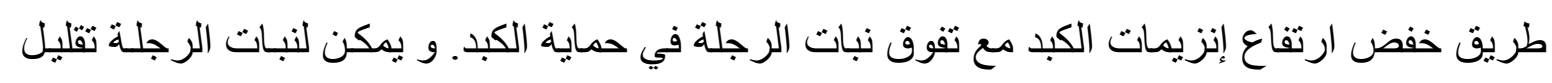

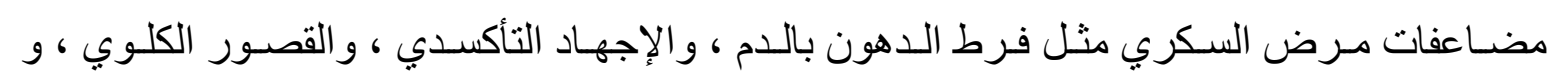
الالتهابات. 